\title{
Terminologi Takwil Menurut al-Māturidī dan al-Ṭabarī
}

\author{
Aisyah Dollah @ Abdullah \\ Universiti Malaya, aisyahabdullah@umt.edu.my \\ Mohd Yakub @ Zulkifli Mohd Yusoff \\ Universiti Malaya, zulkifliy@um.edu.my \\ Nurul Zakirah Mat Sin \\ Universiti Malaya,nuzikra85@yahoo.com
}

\begin{abstract}
Abstrak
Penemuan tafsir Ta'wīlāt Ahl al-Sunnah karangan Abū Manșūr alMāturidī (w.333H/944M) telah membuka dimensi baru dalam disiplin ilmu tafsir. Al-Māturidī yang lebih terkenal sebagai pengasas mazhab Maturidiyah ini pernah hidup sezaman dengan seorang tokoh yang terkenal di bidang tafsir iaitu Muḥammad bin Jarīr al-Ṭabarī (w.310H/921M) pengarang Jāmi 'al-Bayā̄n 'an Ta'wīl Āy al-Qur'ān atau lebih dikenali dengan Tafsīr al-Tabarī. Meskipun tiada catatan sejarah yang menunjukkan bahawa kedua tokoh ini pernah bertemu, namun keduanya sama ada secara sengaja atau tidak telah menggunakan istilah takwil pada tajuk karya masing-masing. Situasi ini telah menarik perhatian pengkaji untuk mengemukakan terminologi takwil menurut alMāturidī dan al-Ṭabarī menerusi karya Ta'wìlāt Ahl al-Sunnah dan Jāmi ‘ al-Bayān 'an Ta'wīl $\overline{A y}$ al-Qur'ān di mana hasil dapatan kajian menemukan bahawa terdapat titik temu pada kedua pengarang ini dalam mengaplikasikan terminologi takwil dalam karya masing-masing.

Kata kunci: takwil, tafsir, Abū Manșūr al-Māturid̄̄ , Muḥammad bin Jarīr al-Ṭabarī, Ta'wīlāt Ahl al-Sunnah, Jāmi' al-Bayān 'an Ta'wīl Āy alQur'ān
\end{abstract}

\section{Terminology of Ta'wīl According to al-Māturidī and al-Ṭabarī}

\begin{abstract}
The discovery of interpretation Ta'wīlāt Ahl al-Sunnah written by Abu Mansoor al - Maturidi (d.333H / 944M) has opened a new dimension in the disciplines of interpretation. Al-Māturidī better known as the founder of this sect Māturidiyah have existed side by a well-known figure in the field of interpretation, namely that Muhammad bin Jarīr al-Tabarī (d.310H / Q.921M ) author Jāmi' al-Bayān 'an Ta'wīl Ay al-Qur'ān, better known as Tafsīr al-Ṭabarī. Although there is no historical record indicating that these two men ever met, but they either intentionally or not have used the term 'ta'will' for the title of their work. This situation has attracted the attention of researchers to present the 'ta' will' terminology according to al-Māturid̄i and al-Ṭabarī through Ta'wīlāt
\end{abstract}


Ahl al-Sunnah and the Jāmi' al-Bayān 'an ta'wīl Ay al-Qur'ān in which that there is a common ground on both authors in terms of applying 'ta' wīl' terminology in their work.

Keywords: ta'wil, tafsir, Abū Manșūr al-Māturid̄̄, Muhammad bin Jarīr al-Ṭabarī, Ta'wīlāt Ahl al-Sunnah, Jāmi' al-Bayān 'an Ta'wīl Āy alQur'ān

\section{Pendahuluan}

Makalah ini secara umumnya membincangkan mengenai terminologi takwil menurut ulama al-Qur'an diikuti dengan terminologi takwil versi al-Māturidī dan al-Ṭabarī. Kemudian, pengkaji akan merumuskan satu terminologi takwil yang paling hampir dengan terminologi versi al-Māturidī dan al-Ṭabarī dengan mendatangkan beberapa contoh persamaan dan perbezaan yang terdapat dalam kedua karya Ta'wīlāt Ahl al-Sunnah dan Jāmi' alBayān 'an Takwīl Āy al-Qur'ān.

\section{Pengenalan Karya al-Māturidī}

Kajian terhadap manuskrip asal karya Ta'wilat Ahl al-Sunnah oleh pengkaji pertama berkenaan karya ini iaitu Mustafid Rahman melalui tesis PhDnya menemukan sebanyak 40 buah manuskrip yang tersimpan di dalam perpustakaan berbeza di seluruh dunia. ${ }^{1}$

Menurut Mustafid Rahman, beliau banyak menggunakan manuskrip yang telah disalin oleh Shahed Ali. Selain itu, beliau juga turut merujuk Sharh Ta'wīlāt al-Qur'ān karangan 'Alā al-Dīn Abū Bakr al-Samarqand $\bar{l}^{2}$ Ketika terdapat kemusykilan atau sesuatu yang munasabah menurutnya pada teks asal kerana pada karya Sharh, pengarangnya Abū Bakr al-Samarqandī telah

1 Kebanyakan manuskrip tersebut adalah merupakan salinan yang sama dan 9 buah di antaranya berada dalam keadaan tidak lengkap. Usaha keras beliau telah menemukan manuskrip yang lengkap pada enam tempat berikut iaitu ; i) Berlin (Tubingen), Or.fol.4156, ii) Besir Agha, Istanbul, 9, iii) Cairo, Dar alKutub, 47, iv) Revan Odasi, Istanbul, 182, v) Shahed Ali, Istanbul, 53 dan vi) Zahiriyya, Dar al-Kutub, Damascus, 495 (Tafsir 99). Lihat Muhammad Mustafizur Rahman, An Introduction to al-Maturidi Ta'wilat Ahl al-Sunna (Bangladesh: Islamic Foundation Bangladesh, 1981), 94-106.

2 Muhammad Mustafizur Rahman, An Introduction to al-Maturidi Ta'wilat Ahl al-Sunna, 94-106. 
melakukan beberapa perubahan dan penambahan untuk menjadikan penjelasan teks asal lebih mudah difahami. ${ }^{3}$

Sementara itu, Majdi Baslum iaitu seorang lagi pentahqiq karya Ta'wīlät Ahl al-Sunnah secara lengkap 30 juz telah merujuk kepada 3 buah manuskrip asal di mana dua di antaranya terdapat di Dār al-Kutub al-Mișriyyah dan sebuah lagi naskah yang berada di Turki. ${ }^{4}$

\section{Pengenalan Karya al-Ṭabarī}

Karya Jāmi ' al-Bayān 'an Ta'wīl Āy al-Qur'ān atau lebih popular dengan Tafsìr al-Tabarī merupakan sebuah hasil karya al-Ṭabarī di bidang tafsir. Beliau menganggap karya ini sebagai pelengkap usaha-usaha yang telah dilakukan oleh para mufassir sebelumnya berdasarkan kata-katanya:

"Ketika aku cuba menjelaskan tafsir al-Qur'an dan menerangkan makna-maknanya yang insya Allah akan menjadi sebuah kitab yang mencakupi semua hal yang perlu diketahui oleh manusia, melebihi seluruh kitab lain yang telah ada sebelumnya. Aku berusaha menyebutkan dalil-dalil yang telah disepakati oleh umat dan yang diperselisihkannya, menjelaskan alasan setiap mazhab yang ada dan menerangkan alasan yang benar menurutku dalam permasalahan berkaitan secara ringkas."

3 Muhammad Mustafizur Rahman, An Introduction to al-Maturidi Ta'wilat Ahl al-Sunna, 117.Menurutnya, untuk setiap kenyataan perubahan atau tambahan yang diambil daripada karya Sharh, beliau akan menyatakan sumber kutipan tersebut.

4 Naskah pertama adalah yang disalin daripada manuskrip simpanan Dār alKutub al-Mișriyyah nombor (6) atau dikenali juga dengan nombor (27306 ب), terdiri daripada 3 jilid. Naskah ini telah ditulis oleh Mustafa Bin Muhammad Bin Ahmad pada tahun 1165H, iaitu merangkumi 656 halaman secara keseluruhannya. Naskah Kedua pula merupakan naskah yang disalin daripada naskah manuskrip yang terpelihara di Maktabah Kubrili di Astanah bernombor 48, dan disimpan di Dār al-Kutub al-Mișriyah bernombor 873 tafsir, ditulis oleh Aḥmad bin Muḥammad Yūsuf al-Khālidī al-Safdī al-Ḥanafī pada tahun 818H. Manakala Naskah Ketiga ditemukan di dalam satu juzuk di Dār alKutub al-Mișriyyah yang turut mengandungi beberapa bahagian daripada naskah Kubrili, Ta'wīlāt Ahl al-Sunnah, 1:342.

5 Muhammad bin Jarīr al-Ṭabarī, Jāmi' al-Bayān 'an Ta'wīl Āy al-Qur'ān (Kaherah: Dār al-Ma‘ārif, t.t.), 1:51. 
Kenyataan ini menunjukkan bahawa al-Ṭabarī bermaksud menerapkan metodologi penulisan tafsirnya sama seperti yang diterapkan oleh beliau dalam karya-karyanya yang lain. Di antara aspek-aspek penting yang diaplikasikan al-Ṭabarī di dalam tafsirannya adalah beliau mengkaji sesuatu isu dengan menumpukan kepada pandangan-pandangan yang sedia ada dengan sandaran dari sanad-sanad dari ayat, hadith dan athar pada setiap ayat al-Qur'an, sehingga karyanya memuatkan keseluruhan pendapat yang ada. Dalam mukadimah karyanya dijelaskan bahawa beliau memohon pertolongan Allah agar menunjukkan kepadanya pandangan yang benar dalam mentafsirkan ayat alQur'an; berkenaan ayat muhkam dan mutashäbih, perkara halal dan haram, umum dan khusus, global dan terperinci, nasikh dan mansukh, jelas dan samar, dan yang hanya menerima pentakwilan atau pentafsiran. ${ }^{6}$

Selain memuatkan pandangan para ulama, al-Ṭabarī juga menyelitkan pandangan peribadinya di hujung perbahasan setiap isu. Tidak memadai hanya sekadar definisi, beliau bahkan menjelaskan pendapat yang paling benar menurutnya setelah menyatakan dalil-dalil selaras dengan kata-katanya, "Aku menjelaskan alasan setiap mazhab dan menetapkan pendapat yang benar menurutku dalam permasalahan tersebut."

\section{Terminologi Takwil Menurut Ulama al-Qur'an}

Isu pengistilahan takwil amat berkait rapat dengan tafsir. Ini kerana, amat sukar untuk dibuat suatu garis panduan atau kaedah khusus yang dipersetujui oleh ulama al-Qur'an berkenaan pengistilahan takwil dan tafsir. Justeru itu, beberapa perbincangan di bawah akan menjelaskan lagi pengistilahan perkataan tersebut.

Tafsir adalah berasal daripada perkataan bahasa Arab fasara. Dalam kamus bahasa, perkataan itu bermaksud menjelaskan, membuka atau menyingkap perkara-perkara yang dapat diterima akal. $^{7}$ Perkataan tafsir, juga boleh diambil daripada perkataan al-

Al-Ṭabarī, Jāmi ‘ al-Bayān 'an Ta'wīl Āy al-Qur'ān, 1:51.

7 Muḥammad Murtaḍā al-Husayn al-Zubaydī, Tāj al-'Arūs min Jawāhir alQāmūs (Beirut: Dār Maktabah al-Ḥayah, t.t.), 7:215. 
tafsirah yang bermaksud alat yang digunakan oleh doktor untuk mengetahui penyakit pesakit. ${ }^{8}$

Huraian di atas menjelaskan bahawa tafsir bermaksud menjelas, menerangkan dan menyingkap hal-hal yang kurang jelas. Apabila dikaitkan dengan al-Qur'an, ia bermaksud berusaha dengan segenap kemampuan yang dimiliki bagi mengetahui secara lebih mendalam isi kandungan di dalam al-Qur'an dengan menjelaskan maknanya dan memberikan klasifikasi pengertian yang sebenarnya.

Di dalam al-Qur'an sendiri, perkataan tafsir bererti penjelasan. Hal ini diambil daripada firman Allah yang berbunyi "wala ya'tunaka bimathālin illā ji'naka bi al-haqqi wa ahsana tafsira" di mana perkataan tafsira bermaksud yang paling baik penjelasannya. $^{9}$

Demikianlah gambaran tafsir menurut bahasa. Manakala tafsir menurut istilah, para ulama berbeza pendapat dalam hal ini disebabkan tidak ada satu kaedah yang tetap yang disepakati bersama. $^{10}$

Ada juga sesetengah ulama memberikan maksud yang sederhana seperti al-Zarkashī. Menurut beliau, tafsir secara istilah ialah:

"Ilmu tentang turunnya suatu ayat, kisah-kisah ayat itu turun, petunjuk sebab ayat itu turun, menerangkan tentang ayat makkiyyah dan madāniyyah, ayat muḥkam dan mutashabih,

8 Jalāl al-Dīn al-Suyūṭị, Al-Itqān fì 'Ulūm al-Qur'ān (Kaherah: Dār al-Turath, t.t.), $4: 167$.

9 Sebab ayat tersebut diturunkan ialah berikutan bantahan keras terhadap orangorang musyrik Mekah yang selalu menghina, mencela dan mengejek Nabi Muhammad SAW serta meragui kenabiannya. Mereka berkata, seandainya baginda itu benar-benar seorang Nabi yang diutuskan oleh Allah SWT, kenapa Allah menyeksanya. Orang-orang musyrik meminta baginda menurunkan alQur'an sekali sahaja iaitu secara serentak seperti yang berlaku kepada kitab Taurat, Injil dan Zabur. Jalāl al-Dīn 'Abd al-Raḥman al-Suyūṭị, al-Durr alManthur (Beirut : Dār al-Fikr, 1993), 6:254.

${ }^{10}$ Al-Suyūṭ̂̄ contohnya memberikan definisi yang panjang lebar dalam hal ini; "Ilmu tentang turunnya ayat dan segala yang berkaitan dengannya, termasuk kisah-kisah, sebab-sebab penurunan ayat, susunan surah makkiyyah dan madāniyyah, ayat muḥkam dan mutashabih, nāsikh mansūkh, khās dan 'àm, mutlaq dan muqayyad, mujmal dan mufassar, halal dan haram, janji dan ancaman, perintah dan larangan, ibarat dan juga contoh-contoh." Lihat alSuyūṭ̂̄, al-Itqān fì 'Ulūm al-Qur'ān, 4:169. 
nasikh mansukh, khas dan 'am, mutlaq dan muqayyad, mujmal dan mufassar. ",11

Ada juga ulama-ulama yang memberikan definisi yang sangat ringkas seperti 'Abd al-'Azịim al-Zurqānī;

"Ilmu yang membahaskan keadaan al-Qur'ān al-Karīm dari segi dilalahnya bagi mencari maksud dari kalam Allah itu mengikut kemampuan manusia." 12

Meskipun terdapat sedikit perbezaan pada definisi tafsir secara istilah di atas, namun pada akhirnya ia menuju kepada tujuan yang satu iaitu menjelas dan menyingkap isi kandungan alQur'an. Apabila dikaitkan makna tafsir secara istilah dengan makna secara bahasa, maka kedua-duanya akan memberikan makna penjelasan dan menerangkan sesuatu.

Takwil pula berasal daripada perkataan Arab iaitu al-awlu Dari segi bahasa ia membawa maksud kembali kepada asal. ${ }^{13}$ Justeru itu, Fayrūz Abādī memberikan contoh wa awwala alkalama takwīlā "dan asal sebuah percakapan adalah takwil" yang bermaksud memikir, merenung dan menjelaskan. ${ }^{14}$

Ulama berbeza pandangan mengenai istilah takwil. Ada yang berpandangan bahawa takwil adalah memalingkan lafaz daripada makna zahir kepada kemungkinan makna yang dilihat selari dengan al-Qur'an dan al-Sunnah. ${ }^{15}$ Sebagai contohnya adalah perkataan al-hayy dan al-mayyit dengan keluarnya burung daripada telur di dalam firman Allah yukhriju al-hayy min almayyit ${ }^{16}$ ia dinamakan tafsir, tetapi apabila maksud itu membawa orang-orang beriman dari kekufuran atau dari kejahilan kepada kealiman, ia dinamakan takwil.

Orang yang ahli dalam bidang takwil mengakui bahawa dalam ayat al-Qur'an itu memiliki makna yang zahir dan batin. Ilmu zahir hanya boleh dicapai melalui makna zahir sesuatu lafaz.

${ }^{11}$ Muhammad 'Abd al-'Aẓ̄ìm al-Zurqān̄̄, Manāhil al- 'Irfānn (Beirut: Dār al-Fikr, t.t.), 2:3.

12 'Abd al-Mun'īm al-Khifni, al-Mu ‘jam al-Falsafì (Kaherah: Dār al-Syarqiyyah, 1990), 52.

13 Al-Khifnī, al-Mu jam al-Falsafì, 52.

${ }^{14}$ Mujīd al-Dīn Muhammad bin Ya'qūb al-Fayrūz Abādī, Qāmus al-Muhịt (Kaherah: Mu'assasah al-Halabī wa Syurakah li al-Nathr wa al-Tawji`, t.t.), $3: 331$.

15 Al-Khifni, al-Mu'jam al-Falsafi, 52.

${ }^{16}$ Surah al-An‘ām 6:95. 
Begitu juga dengan ilmu batin, ia dicapai dengan makna batin. Ini kerana, setiap ilmu itu mempunyai ahli dan cara tersendiri yang tidak dimiliki oleh orang lain. Ahli ilmu zahir akan mentakwil alQur'an melalui naqal (al-Qur'an dan al-Hadith) dan akal, sementara ahli batin akan mentakwil al-Qur'an melalui bisikanbisikan dan ilham.

Takwil dan tafsir hakikatnya merupakan istilah yang difahami dengan baik oleh generasi awal. Namun, peredaran masa yang panjang menyebabkan kefahaman mengenai terminologi keduanya tidak sampai kepada generasi kemudian sehingga menimbulkan kesamaran sehingga perbincangan mengenainya sering dimuatkan di dalam kitab-kitab tafsir para mufassir.

Para pengarang tafsir, mereka tidak membezakan kedua istilah tersebut untuk menamakan kitab karangan mereka. AlZamakhsharī menamakan kitabnya "al-Kashf 'an Haqā'iq alTanzīl wa 'Uyūn al-Aqāwil fì Wujūh al-Ta'wìl'. Al-Bayḍāwī menamakan kitabnya dengan "Anwār al-Tanzīl wa Asrār alTa 'wil'". Daripada pengarang dua kitab tersebut tidak memberikan petunjuk kepada kita bahawa cara mereka dalam menerangkan kitab al-Qur'an dengan cara takwil bukannya tafsir atau sebaliknya.

Namun, terdapat juga perselisihan di kalangan mereka. Iaitu ada di kalangan ulama al-Qur'an yang memberikan garis panduan tertentu kepada makna tafsir dan takwil secara istilah. Golongan ini meyakini bahawa tafsir bersifat lebih umum daripada takwil. Tafsir banyak merujuk kepada zahir sedangkan takwil merujuk kepada perkara batin. Tafsir dikaitkan dengan riwayah dan takwil dikaitkan dengan dirayah atau akal dan pandangan-pandangan lain.

Walaupun ada yang melontarkan pandangan untuk kedua istilah tersebut, namun al-Naysābūrī menyatakan bahawa mereka pada hakikatnya juga amat sukar untuk menjustifikasikan perbezaan di antara kedua istilah tersebut. ${ }^{17}$ Pengkaji berpandangan, takwil bersifat umum sedangkan tafsir bersifat

${ }^{17}$ Al-Hiifni, Al-Mu`jam al-Falsafì, 167. Al-Naysabūrī misalnya pernah menyatakan bahawa di zaman kita terdapat sejumlah mufassir yang cerdik pandai, namun apabila ditanya perbezaan di antara tafsir dan takwil mereka menjadi bingung, Jalāl al-Dīn al-Suyūṭī, Al-Itqān fì 'Ulūm al-Qur'ān (Cairo: Dār al-Ḥadīth, 2004), 2:449. 
lebih khusus iaitu tafsir sudah pasti kebenarannya daripada sumber yang ma'thūr sedangkan takwil sebaliknya. Secara ringkasnya, takwil merupakan hasil daripada tafsir atau tafsir merupakan langkah menuju takwil baik hasil tersebut berupa penguatan kepada salah satu hadith, pandangan ulama atau hasil daripada beberapa pandangan tersebut sekitar pemahaman makna bahasa.

Tidak dinafikan penguatan kepada salah satu daripada hasil di atas tidak lepas daripada peranan akal atau dirāyah, kerana bagaimanapun sebuah hasil takwil itu diperolehi daripada beberapa kemungkinan makna di atas jelas ia memerlukan peranan akal atau dirāyah. Justeru, pengkaji cenderung dengan pandangan al-Alūsī yang mengatakan bahawa tafsir banyak berkaitan dengan riwāyah sedangkan takwil banyak berkaitan dengan dirāyah atau akal. $^{18}$

Bertitik tolak daripada dirāyah itu munculnya dua jenis takwil iaitu takwil baik dan takwil tercela. Dikatakan baik menurut al-Zarkashī apabila ianya diambil daripada sumber manqūl (alQur'an dan al-Hadith), pandangan para sahabat, tabiin, diambil daripada kemutlakan bahasa dan takwil yang menepati syariat. ${ }^{19}$

Daripada pandangan al-Zarkashī di atas bila dikaitkan pandangan ulama yang mengatakan bahawa "tafsir banyak berkaitan dengan riwāyah sedangkan takwil banyak berkaitan dengan dirāyah atau akal," menunjukkan bahawa semua jenis tafsir itu baik kerana ianya menepati salah satu daripada syarat yang telah ditetapkan oleh al-Zarkashī di atas iaitu berpegang kepada riwāyah berupa al-Qur'an dan al-Hadith, yang ada hanyalah takwil baik dan takwil buruk. Dikatakan takwil yang baik apabila peranan akal tidak dibiarkan terkeluar daripada landasan syariat dan dikatakan takwil yang buruk apabila peranan akal terkeluar daripada syarat-syarat di atas.

\section{Terminologi Takwil Menurut al-Māturidī}

Pada bahagian pendahuluan kitabnya Ta'wīlāt Ahl al-Sunnah, alMāturidī telah meletakkan satu pengenalan umum bagi membezakan definisi takwil dan tafsir. Tafsir ialah apa yang

${ }^{18}$ Shihāb al-Dīn al-Sayȳ̄d Maḥmūd al-Ālūsī, Rūh al-Ma 'ānī (Beirut: Dār al-Fikr, 1987), 1:5.

${ }^{19}$ Badr al-Dīn al-Zarkashī, Al-Burhān fì 'Ulum al-Qur'ān (t.tp.: t.p., t.t.), 2:156161. 
dinukilkan daripada para sahabat Rasulullah SAW dan takwil adalah apa yang diambil daripada para fuqaha. ${ }^{20}$ Definisi ini diambil kira kerana para sahabat menyaksikan setiap peristiwa yang berlaku ketika al-Qur'an diturunkan dan hanya generasi mereka yang mempunyai autoriti dan lebih mengetahui secara mendalam setiap peristiwa tersebut kerana berhadapan secara langsung dengan suasana penurunan al-Qur'an. ${ }^{21}$

Sementara takwil adalah keterangan akhir sesuatu perkara, di ambil dari perkataan (Āla-ya'ūlu) yang bermaksud kembali sebagaimana yang dikatakan; sekiranya usaha mengembalikan maksud takwil kepada sesuatu maksud, maka itulah yang dimaksudkan dan dituju, namun usaha itu tidaklah seketat yang terdapat pada tafsir kerana takwil tidak memerlukan penyaksian kepada Allah SWT iaitu tidak boleh mengatakan bahawa inilah yang dikehendaki Allah, tetapi hendaklah mengatakan bahawa pandangan ini dikembalikan kepada pandangan tertentu yang dimaklumi sebagai perkataan manusia biasa. ${ }^{22}$ Sementara Allah SWT lebih mengetahui hakikat kebenaran dari hikmahNya.

Contohnya adalah perselisihan ahli tafsir pada firman Allah SWT (Alhamdulillah). Sebahagian mereka berpendapat bahawa Allah SWT memuji diri-Nya dan sebahagian yang lain berpandangan Allah SWT memerintahkan untuk memujiNya. ${ }^{23}$ Siapa yang berpandangan bahawa maksudnya hanya sebagaimana yang terdapat pada riwayat tertentu sahaja, maka aktiviti tersebut adalah mentafsirkan sementara takwil adalah mereka yang berpandangan bahawa ditujukan segala pujian kepada yang layak mendapat pujian, mengarahkan perintah bersyukur kepada Allah SWT, dan Allah SWT jualah yang lebih mengetahui apa maksud yang dikehendakiNya. ${ }^{24}$ Tafsir hanya mewakili satu pandangan sementara takwil mewakili banyak pandangan. ${ }^{25}$

Secara ringkasnya, al-Māturidī mendefinisikan tafsir sebagai sesuatu yang pasti bahawa ianya benar-benar dimaksudkan oleh Allah SWT sedemikian. Pandangan beliau jika diperhatikan adalah

\footnotetext{
${ }^{20}$ Majdi Baslum, Ta'wīlāt Ahl al-Sunnah Tafsīr al-Māturidī (Beirut: Dār Kutub al-'Ilmiyyah, 2005), 1:349.

${ }^{21}$ Majdi Baslum, Ta'wìlāt Ahl al-Sunnah Tafsīr al-Māturid̄̄, 1:349.

${ }^{22}$ Majdi Baslum, Ta'wīlāt Ahl al-Sunnah Tafsīr al-Māturid̄̄, 1:349.

${ }^{23}$ Majdi Baslum, Ta'wīlāt Ahl al-Sunnah Tafsīr al-Māturid̄̄, 1:349.

${ }^{24}$ Majdi Baslum, Ta'wīlàt Ahl al-Sunnah Tafsīr al-Māturid̄i, 1:349.

${ }^{25}$ Majdi Baslum, Ta'wīlāt Ahl al-Sunnah Tafsīr al-Māturidī, 1:349.
} 
selari dengan pandangan al-Zarkasḥ̄ dan al-Zurqan̄̄ iaitu meletakkan tafsir pada kedudukan utama daripada takwil dan mestilah berdasarkan sumber hukum yang berautoriti menurut disiplin ulum al-Qur'an. Termasuk dalam kefahaman ini juga adalah pandangan al-Ālūsī yang menyatakan bahawa tafsir adalah lebih kepada riwāyah dan takwil adalah dirāyah.

Sementara, takwil menurut al-Māturidī adalah merupakan hasil ijtihad seorang mujtahid tanpa menyatakan persaksian bahawa ia adalah daripada Allah SWT. Atas kefahaman inilah yang mendorong generasi awal seperti al-Māturidī lebih selesa meletakkan nama takwil pada tajuk karya kerana sikap tawaduk mereka yang menyedari bahawa apa yang ditulis oleh mereka pasti mengandungi kesalahan dan menyerahkan kepada Allah atas kesilapan yang tidak disengajakan. Namun begitu, jika ditelusuri karya Ta'wīlāt Ahl al-Sunnah, al-Māturidī tidaklah sewenangnya memuatkan sebuah takwilan meskipun tidak disandarkan penyaksiannya kepada Allah SWT, melainkan setelah melalui proses istidlal, analisis, ijtihad dan syarat yang ketat sebagaimana syarat layaknya seorang mufasir.

\section{Terminologi Takwil Menurut al-Ṭabarī}

Meskipun al-Ṭabarī tidak menerangkan secara jelas mengenai terminologi tafsir dan takwil sama ada menyamakannya atau membezakannya, namun penelitian terhadap kitab takwil "Jāmi" al-Bayān 'an Ta'wīl ay al-Qur'ān" menunjukkan bahawa beliau membezakan kedua istilah tersebut walaupun beliau sering menggunakan perkataan takwil bukannya tafsir seperti yang digunakan oleh ulama-ulama takwil yang terkenal sekarang ini. Di antara istilah yang beliau sering gunakan adalah; al-qawl fi takwìl, takwīl hadhihi al-Ayyah, qāla 'adad min ahl al-takwīl, wa qāla ahl al-takwīl, ikhtilaf ahl al-takwīl, kesemua istilah-istilah tersebut bermaksud tafsir. ${ }^{26}$

Al-Ṭabarī pada umumnya menyamakan penggunaan tafsir dan takwil dari aspek bahasa. Walaupun beliau menyamakan kedua istilah tersebut, namun beliau meletakkan perkataan takwil pada peringkat kedua iaitu proses takwil itu harus dilakukan setelah adanya tafsir terlebih dahulu. Takwil tidak boleh dilakukan

${ }^{26}$ Husayn al-Dhahabī, Al-Tafsìr wa al-Mufassirūn (Tehran: Avand Danesh LTD, 1995), 19. 
tanpa melalui proses tafsir terlebih dahulu dan pada masa yang sama tidak semua proses tafsir itu dikatakan takwil. ${ }^{27}$

Dalam melakukan proses takwil, al-Ṭabarī biasanya menggunakan perkataan al-qawl fi takwìl dan diletakkan apabila memulakan pentakwilan ayat, perkataan ikhtilaf ahl al-takwìl atau qāla 'adad min ahl al-takwìl digunakan bagi menghuraikan beberapa pendapat ulama berkaitan ayat yang akan beliau takwilkan. Manakala perkataan takwīl hadhihi al-āyah selalunya digunakan bagi memberikan kesimpulan atau ulasan kepada beberapa pendapat ulama al-Qur'an atau memberikan alasan kepada pendapat-pendapat tersebut. ${ }^{28}$

Semasa menggunakan perkataan takwil, al-Ṭabarī tidak membatasi kepada mentakwil ayat tertentu sahaja, akan tetapi beliau menggunakannya bagi mengulas beberapa pendapat ulama al-Qur'an. Selain itu, beliau juga menggunakan kata tersebut bagi membincangkan makna-makna huruf, i'rab ayat, kalimah dan sebagainya. Contoh huruf inna dan liman di dalam ayat wa in kuntum min qablihi liman al-d̄ālīn ${ }^{29}$ Di kalangan orang-orang arab, mereka mentakwil inna kepada makna mā dan lam yang ada pada liman kepada makna illā. ${ }^{30}$

Perbincangan mengenai bahagian manakah yang termasuk di dalam tafsir dan bahagian mana pula yang termasuk takwil adalah sesuatu yang rumit. Bertitik tolak daripada metodologi yang beliau garapkan dalam penulisan kitabnya, pengkaji berusaha menemukan titik perbezaan tersebut secara saksama.

Dalam pengenalan kitabnya pada juzuk pertama, al-Ṭabarī mentakwil surah al-Fātiḥah, "basmalah" dan surah al-Baqarah serta kebanyakannya menggunakan perkataan-perkataan yang merujuk kepada perkataan tafsir seperti al-hujjah min almufassirīn, mā qālahu sā’ir al-mufassirīn atau juga dengan

${ }^{27}$ Yahya Nuryadi, "Takwil dan Kesannya kepada Pengajian Tafsir: Analisis Terhadap Pemikiran Ibn Jarir al-Tabari dalam Mentafsir Ayat-ayat al-Qur'an" (disertasi, Jabatan al-Qur'an dan al-Hadith, Akademi Pengajian Islam, Universiti Malaya, 2005), 157.

28 Abū Ja'far Muhammad bin Jarīr al-Ṭabarī, Tafsīr al-Ṭabarī al-Musammā Jāmi ‘ alBayān 'an fì Ta' wīl al-Qur'ān ( Lubnan: Dār al-Kutub al-'Ilmiyyah,2005), 2:401.

29 Al-Ṭabarī, Tafsīr al-Ṭabarī al-Musammā Jāmi ‘ al-Bayān 'an fì Ta'wīl alQur'ān, 2:398. Lihat Surah al-Baqarah 2:198.

30 Al-Ṭabarī, Tafsīr al-Tabarì al-Musammā Jāmi 'al-Bayān 'an fì Ta'wīl alQur'ān, 2:398. 
perkataan lain yang menunjukkan kepada makna tersebut seperti tarjamah al-Qur'ān dan sebagainya. Istilah-istilah tersebut banyak ditemukan di dalam kitab-kitabnya terutama pada bahagianbahagian yang telah dihuraikan tadi. Berbeza pada juzuk-juzuk seterusnya di mana al-Ṭabarī tidak lagi menggunakan istilah tersebut. Beliau cukup hanya menggunakan satu istilah sahaja iaitu al-takwīl.

Metodologi yang beliau gunakan itu, sekaligus menunjukkan bahawa terdapat al-hujjah min al-mufassirin atau selainnya yang telah disebutkan di atas merujuk kepada pendapat-pendapat ulama takwil yang beliau huraikan sebelumnya. Ini menandakan pendapat-pendapat ulama takwil sewaktu al-Ṭabarī melakukan proses pentakwilan itu dinamakan tafsir bukannya takwil. Dengan kata lain, takwil adalah hasil kesimpulan al-Ṭabarī sendiri daripada pendapat-pendapat ulama takwil sebelumnya sama ada beliau berpegang kepada salah satu pendapat yang berbentuk hadith, qiraat, kaedah bahasa, pendapat ulama takwil tentang makna lafaz dan sebagainya atau beliau mengemukakan pandangan peribadinya. ${ }^{31}$

Takwil menurut al-Tabarī lebih menjurus kepada pandangan peribadi beliau setelah melalui analisis, penelitian dan pertimbangan daripada beberapa pendapat yang sedia ada. ${ }^{32}$ Sementara pendapat-pendapat ulama takwil yang beliau huraikan sewaktu melakukan proses takwil itu dinamakan tafsir. ${ }^{33}$ Namun, termasuk dalam bahagian takwil adalah huraian beliau terhadap beberapa pandangan ulama takwil tanpa memberikan sebarang komentar semasa sesi perbincangan tersebut. ${ }^{34}$

Huraian di atas adalah selari dan tidak menyalahi apa yang telah diterapkan oleh al-Ṭabarī di dalam kitabnya. Namun al-

${ }^{31}$ Yahya Nuryadi, "Takwil dan Kesannya kepada Pengajian Tafsir: Analisis Terhadap Pemikiran Ibn Jarir al-Tabari dalam Mentafsir Ayat-ayat al-Qur'an", 166.

${ }^{32}$ Yahya Nuryadi, "Takwil dan Kesannya kepada Pengajian Tafsir: Analisis Terhadap Pemikiran Ibn Jarir al-Tabari dalam Mentafsir Ayat-ayat al-Qur'an”, 166.

${ }^{33}$ Yahya Nuryadi, "Takwil dan Kesannya kepada Pengajian Tafsir: Analisis Terhadap Pemikiran Ibn Jarir al-Tabari dalam Mentafsir Ayat-ayat al-Qur'an”, 166.

${ }^{34}$ Yahya Nuryadi, "Takwil dan Kesannya kepada Pengajian Tafsir: Analisis Terhadap Pemikiran Ibn Jarir al-Tabari dalam Mentafsir Ayat-ayat al-Qur'an", 166. 
Tabarī ketika memulakan takwil ayat daripada al-Qur'an menyebut al-qawl fì takwīl qawlahu ta' âlā. Padahal beliau hanya menitik beratkan makna takwil secara bahasa sebagai kerangka awal menuju takwil secara istilah yang digunakan olehnya.

Secara keseluruhannya, pengkaji mendapati baik al-Māturidī mahupun al-Tabarī membezakan istilah tafsir dan takwil di mana keduanya lebih cenderung dengan pandangan al-Ālūsī yang menekankan bahawa tafsir adalah riwāyah dan takwil adalah dirāyah. Meskipun takwil adalah dirāyah, ia tertakluk kepada medan ijtihad yang khusus serta mempunyai syarat yang ketat sebagaimana telah disepakati dan ditetapkan oleh ahli di bidang alQuran seperti al-Zarkashī, al-Suyūṭ̂̀ dan al-Zurqanī.

\section{Contoh Takwilan al-Māturidī dan al-Ṭabarī}

Hasil analisis kajian perbandingan di antara dua tokoh ini akan mendedahkan aspek persamaan dan perbezaan yang wujud dari segi pendekatan metodologi takwil yang ditempuh oleh setiap pengarang. Sehingga akhirnya pembaca dapat melihat perbandingan pendekatan takwil yang ditempuh oleh kedua pengarang dalam beberapa isu berikut.

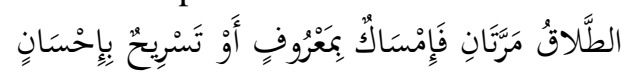

Al-Baqarah 2:229

Terjemahan: Talak (yang boleh dirujuk kembali itu hanya) dua kali. sesudah itu bolehlah ia (rujuk dan) memegang terus (isterinya itu) dengan cara yang sepatutnya atau melepaskan (menceraikannya) dengan cara yang baik.

Para ahli takwil berbeza pandangan mengenai takwilan ayat di atas. ${ }^{35}$ Sebahagian mereka menyatakan bahawa ayat ini menjadi dalil bilangan talak yang dibolehkan untuk merujuk kembali isteri setelah diceraikan dan tempoh iddah yang dibenarkan. ${ }^{36}$ Perkataan "tasrīh bi ihsān" (menceraikannya dengan cara yang baik) dalam ayat di atas telah ditakwilkan oleh al-Māturidī sebagai talak ketiga merujuk kepada kenyataan Nabi SAW ketika ditanya maksud

\footnotetext{
${ }^{35}$ Al-Ṭabarī, Jāmi ' al-Bayān 'an Ta'wīl Āy al-Qur'ān, 2:469.

${ }^{36}$ Sebelum turunnya ayat ini, masyarakat Arab jahiliah boleh menceraikan dan merujuk isteri-isteri mereka sewenangnya sehinggalah Islam datang menetapkan dan menghadkan bilangan talak dan tempoh iddah. Lihat alȚabarī, Jāmi ' al-Bayān 'an Ta'wīl Āy a-Qur'ān, 2:469.
} 
"tasrīh bi ihsān" baginda telah menjawab: "ia adalah talak ketiga", 37

Sementara al-Ṭabarī pula telah mentakwilkan maksud "tasrīh bi ihsān" dengan merujuk riwayat al-Suddī dan al-Ḍahhāk yang menyatakan bahawa bilangan talak yang dibenarkan rujuk adalah hanya sebanyak dua kali, iaitu hendaklah dirujuk setiap kali talak dengan cara yang baik dan menceraikannya dengan cara yang baik. $^{38}$

Meskipun terdapat sedikit perbezaan pada versi takwilan alMāturidī dan al-Țabarī, namun jika diperhalusi keduanya bersepakat pada makna yang sama iaitu istilah talak ketiga adalah merujuk kepada para suami yang menceraikan isterinya kali pertama atau kedua hanya boleh merujuk isteri mereka sebanyak dua kali sahaja kerana pada talak kali ketiga sudah tidak boleh dirujuk lagi.

Selain itu, pembaca boleh melihat perbezaan versi takwilan kedua pengarang ini dalam isu kesucian seorang wanita dari haid secara zahir dan hukumnya.

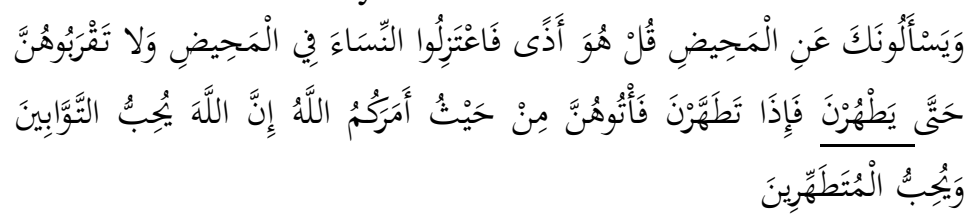

Al-Baqarah 2:222

Terjemahan: Dan mereka bertanya kepadamu (Wahai Muhammad), mengenai (hukum) haid. katakanlah: "Darah haid itu satu benda yang (menjijikkan dan) mendatangkan mudarat". Oleh sebab itu hendaklah kamu menjauhkan diri dari perempuan (jangan bersetubuh dengan isteri kamu) Dalam masa datang darah haid itu, dan janganlah kamu hampiri mereka (untuk bersetubuh) sebelum mereka suci. kemudian apabila mereka sudah bersuci maka datangilah mereka menurut jalan yang diperintahkan oleh Allah kepada kamu. Sesungguhnya Allah mengasihi orang-orang yang

37 Al-Maturidi tidak menyebutkan riwayatnya berkemungkinan kerana terlalu banyak riwayat berkenaan ayat ini.

${ }^{38}$ Pendapat ini bersesuaian dengan zahir ayat yang membolehkan suami merujuk kembali isterinya hanya sebanyak dua kali. Al-Tabari, Al-Ṭabarī, Jāmi ' alBayān 'an Ta'wīl Āy al-Qur'ān, 2: 472. 
banyak bertaubat, dan mengasihi orang-orang yang sentiasa mensucikan diri.

Al-Māturidī mengatakan lafaz hatta yațurna mengandungi dua pengertian dari sudut bahasa berdasarkan bacaan qiraat sama ada mendammahkan $h a$ dan mentakhfifkannya ataupun memfathahkan dan mentashdìdkannya. Bacaan secara takhfif membawa maksud sehingga berhenti darahnya dan bacaan secara tashdīd pula menunjukkan bahawa sudah halal bagi para suami mendekati isteri mereka selepas mandi. Pandangan al-Māturidī dalam isu ini adalah seorang perempuan jika kebiasaan hari haidnya adalah sepuluh hari maka halal bagi suaminya untuk bersama dengannya sebelum mandi, ${ }^{39}$ dan sekiranya kebiasaan hari haidnya adalah kurang daripada sepuluh hari maka tidak halal untuk bersama dengannya melainkan setelah dia mandi. ${ }^{40}$

Al-Țabarī sebagaimana al-Māturidī mengatakan bahawa para ahli qiraat berbeza pendapat mengenai bacaan ayat tersebut, sebahagian ada yang membacanya hatta yațhurna iaitu mendammahkan ha dan meringankannya dan sebahagian yang lain pula membaca dengan fathah dan tashdìd. Sementara bacaan dammah tanpa tashdīd membawa erti "Dan janganlah kamu mendekati wanita pada masa haidnya sehingga darahnya berhenti dan mereka telah mensucikan diri". Walau bagaimanapun, pandangan yang paling benar menurut al-Ṭabarī adalah mereka yang membaca hatta yathurna dengan tashdīd dan fathah, yang bermakna: sehingga mereka mandi kerana adanya ijmak umat yang mengatakan bahawa diharamkan bagi lelaki untuk mendekati isteri mereka setelah berhenti darah haid sehingga mereka mandi. ${ }^{41}$

Di samping itu, pengkaji ingin membawakan sebuah lagi contoh perbezaan pendekatan takwil yang ditempuh oleh alMāturidī dan al-Ṭabarī dalam mentakwilkan "ayyamin ma 'dudāt" seperti berikut.

\footnotetext{
${ }^{39}$ Ini adalah pandangan jumhur fuqaha termasuk Malikiyah, Shāfi‘iyyah dan Hanabilah. Lihat Majdi Baslum, Ta'wīlāt Ahl al-Sunnah Tafsīr al-Māturidī, 2:134-135.

${ }^{40}$ Majdi Baslum, Ta'wīlāt Ahl al-Sunnah Tafsīr al-Māturid̄̄, 2 :134-135.

${ }^{41}$ Al-Ṭabarī, Tafsìr al-Ṭabarì al-Musammā Jāmi' al-Bayān 'an fì Ta'wīl alQur'ān, 2: 397.
} 


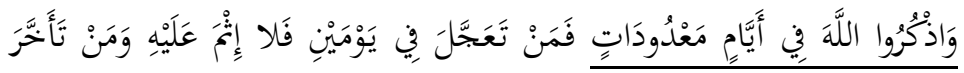

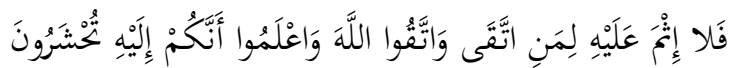

Al-Baqarah 2:203

Terjemahan:dan sebutlah kamu akan Allah (dengan takbir semasa mengerjakan Haji) dalam beberapa hari yang tertentu bilangannya. Kemudian sesiapa yang segera (meninggalkan Mina) pada hari yang kedua, maka ia tidaklah berdosa dan sesiapa yang melambatkan (meninggalkan mina) maka ia juga tidaklah berdosa; (ketiadaan dosa itu ialah) bagi orang yang bertaqwa dan hendaklah kamu bertaqwa kepada Allah dan ketahuilah sesungguhnya kamu akan dihimpunkan kepadaNya.

Secara umumnya, ahli takwil berpandangan bahawa wadhkur Allāh fì ayyamin ma'dudāt adalah merujuk kepada amalan mengingati Allah SWT dengan mengEsakan dan membesarkanNya, pada hari yang dikhususkan iaitu pada hari melontar jamrah. ${ }^{42}$ Di antara yang cenderung dengan pandangan ini adalah al-Ṭabarī sehingga beliau telah mendatangkan sejumlah riwayat mengenainya. Berikut didatangkan beberapa hadith yang telah dibawakan oleh al-Ṭabarī daripada riwayat Aishah r.a dan Abū Hurayrah r.a. yang bermaksud:

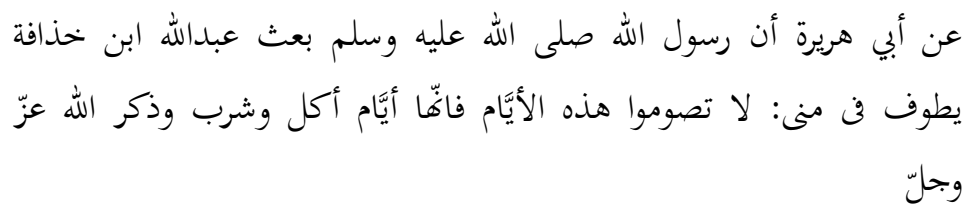

Terjemahan: Dari Abū Hurayrah, sesungguhnya Rasulullah SAW telah mengutus 'Abd Allāh bin Khudhafah mengelilingi Mina. Hari ini janganlah kamu semua berpuasa, kerana hari ini adalah hari untuk makan, minum dan zikir kepada Allah SWT. $^{43}$

${ }^{42}$ Allah memerintahkan agar hamba-hambaNya memperbanyakkan bertakbir semasa melontar jamrah. Al-Ṭabarī, Tafsīr al-Ṭabarī al-Musammā Jāmi ‘ alBayān 'an fì Ta'wīl al-Qur'ān, 2:314. Al-Ṭabarī menggunakan lafaz "al-qawl fìtakwìl qawluhu ta 'ālā'”.

43 Al-Ṭabarī, Tafsìr al-Ṭabarī al-Musammā Jāmi ' al-Bayān 'an fì Ta'wīl alQur'ān, 2:415. Hadith riwayat Aḥmad bin Muḥammad bin Ḥanbal Abū 'Abd Allāh al-Shaybān̄, Musnad al-Imām Ahmad bin Hanbal, no.hadith 10286 (Jeddah: Dār al-Minhaj, 2008), 3:494. Disahihkan oleh Albān̄̄. Lihat juga 
Selain itu, riwayat daripada $\bar{A}$ 'ishah r.a yang bermaksud:

عن عائشة أنّ رسول الله قال : إنّ هذه الأيَّام أيَّام أكل وشرب وذكر الله

Terjemahan: Dari Aisyah, sesungguhnya Rasulullah SAW bersabda: "Hari ini adalah hari untuk makan, minum, dan zikir kepada Allah. ${ }^{44}$

Adapun al-Māturidī , beliau kelihatan lebih cenderung dengan pandangan Abū Hanīfah yang menyatakan bahawa ayyam al-ma'dudāt adalah hari menyebut nama Allah dengan pengorbanan dan penyembelihan pada hari $\mathrm{Nahar}^{45}$ dan dua hari selepasnya berdasarkan riwayat daripada 'Alī r.a yang turut diriwayatkan oleh Ibn 'Umar r.a sesungguhnya Rasulullah SAW bersabda:

$$
\text { الأيام المعدودات: يوم النحر ويومان بعده , اذبح في أيها شئت وأفضلها أولها }
$$

Terjemahan: Hari-hari yang ditentukan, iaitu hari Nahar dan dua hari selepasnya, maka lakukanlah sembelihan dari manamana hari yang kamu inginkan tetapi yang paling utama adalah sembelihan pada hari pertama. ${ }^{46}$

Baik al-Māturidī mahupun al-Ṭabarī bersetuju dengan pandangan majoriti ulama takwil bahawa ayat di atas adalah merujuk kepada amalan mengingati Allah SWT dengan mengEsakan dan membesarkanNya, pada hari yang dikhususkan iaitu pada hari Raya Aidil Adha merujuk kepada 10,11, dan 12 zulhijjah. Hanya al-Tabarī mentakwilkan dengan mendatangkan hadith yang menggalakkan umat Islam merayakan hari tersebut dengan makan dan minum sambal mengingati Allah, sementara alMāturidī pula mendatangkan hadith yang mengingatkan mengenai hari pengorbanan dengan penyembelihan haiwan korban.

Kesimpulannya, kesemua amalan-amalan yang dinyatakan oleh hadith yang didatangkan oleh al-Māturidī dan al-Ṭabarī adalah saling melengkapi antara satu sama lain kerana semuanya

Muhammad Nāṣir al-Dīn al-Albānī, Silsilah al-Ahāàìth al-Ṣahīhah, no.hadith 3573 (Riyadh: Maktabah al-Ma‘ārif al-Nashr, 2002), 7:1539.

${ }^{44}$ Hadith riwayat Muslim, Kitab al-Șiyam, bab Taḥī̄m Șawm Ayyām Tashrīq, no.Hadith 1141. Lihat Abū al-Husayn Muslim bin al-Hajjāj bin Muslim, "Sahih Muslim", dalam Mawsu'āt al-Hadīth al-Shārif al-Kutub al-Sittah, ed. Șalị̣ bin 'Abd al-'Az̄̄z Āli al-Shaykh (Riyadh: Dār al-Salam, 2000), 3:860.

45 Hari Raya Aidiladha atau 10 zulhijjah.

${ }^{46}$ Majdi Baslum, Ta'wīlāt Ahl al-Sunnah Tafsīr al-Māturid̄̄, 2:98. 
adalah termasuk di dalam perkara-perkara yang disyariatkan semasa hari Raya Aidil Adha.

\section{Penutup}

Kajian terhadap latar belakang pendidikan, kelahiran dan politik semasa kehidupan tokoh ini menunjukkan bahawa elemen tersebut mempengaruhi ilmu dan pemikiran kedua tokoh yang dikaji iaitu al-Māturidī dan al-Ṭabarī. Walau bagaimanapun, pengaruh pendidikan adalah merupakan faktor yang paling dominan dan mempengaruhi cara pandang serta pendekatan yang ditempuh oleh kedua tokoh ini dalam melakukan proses takwil.

Al-Māturidī alumni madrasah ra'yu berfahaman aliran Abū Hanīfah dan al-Ṭabarī pula dari latar belakang mazhab Syafie dan akhirnya mengasaskan mazhab al-Jarīrī. Kedua tokoh ini meskipun hidup sezaman, tetapi tiada catatan bahawa keduanya pernah bertemu, namun kelihatannya pengaruh al-Ṭabarī lebih dominan berbanding al-Māturid̄̄ di bidang tafsir. Al-Ṭabarī melalui pendekatan takwilnya bil Ma'thur dan al-Māturidī juga mengetengahkan metodologi yang sama hanya sahaja aliran ra'yu yang mempengaruhinya menyebabkan takwilan beliau seperti berada pertengahan di antara bi al-ma'thūr dan ra'yu.

Tafsir Ta'wìlāt Ahl al-Sunnah telah menyingkap ketokohan al-Māturidī di bidang tafsir dengan cukup jelas. Faktor masa yang tidak begitu jauh dengan sumber yang ma'thur dan generasi salaf menyebabkan takwilan beliau tidaklah tersasar jauh sebagaimana yang terjadi pada generasi hari ini yang mentakwilkan al-Qur'an sewenangnya. Baik al-Māturidī mahupun al-Ṭabarī masing-masing telah mengusahakan suatu hasil kerja yang luar biasa dalam menyampaikan ilmu dan kefahaman Islam kepada masyarakat Islam melalui karya Ta'wīlāt Ahl al-Sunnah dan Tafsìr al-Tabarì.

Paparan di atas menjelaskan kepada kita bahawa terdapat perbezaan yang jelas di antara tafsir dan takwil khususnya dari aspek istilah baik menurut al-Ṭabarī mahupun al-Māturidī. Iaitu tafsir menjurus kepada aspek riwāyah atau syarat yang ditetapkan di atas. Sementara takwil pula menjurus kepada aspek dirāyah dengan syarat tidak bertentangan dengan sumber riwāyah dan kaedah yang ditetapkan oleh pakar dalam disiplin ilmu al-Qur'an. Oleh itu, tidak ada yang namanya tafsir yang tercela yang ada hanyalah takwil yang tercela, apabila tidak menepati syarat di atas, 
dikatakan baik atau sebaliknya. Takwil inilah yang diistilahkan oleh ulama dengan takwil bi al-ra'y al-mahmūd atau takwil terpuji.

\section{Bibliografi}

'Alī, Abū al-Khayr Muḥammad Ayyub. 'Aqīdat al-Islām wa alImām al-Māturid̄̄ . Bangladesh: al-Muassasah al-Islāmiyyah, 1983.

Abī Khallikan, Abū al-'Abbas Shams al-Dīn Aḥmad bin Muhammad bin. Wafāyāt al-A yān wa Anbā' al-Zamān. Beirut: Dār al-Thaqafah, t.t.

Aḥmad 'Atiyyah Allāh, al-Qāmūs al-Islāmī. Kaherah: Maktabah al-Nahḍah al-Mișriyyah, 1976.

Ahmad Amin. Zuhr al-Islām. Kaherah: Lajnah al-Ta'līf wa alTarjamah wa al-Nashr, 1952.

Al-'Asqalānī, Shihāb al-Dīn Abī al-Faḍl Aḥmad bin 'Alī bin Hajar. Tahdhīb al-Tahdhīb. India: Dār al-Ma‘ārif alNizamiyah, 1904.

Al-Ālūsī, Shihāb al-Dīn al-Sayyīd Maḥmūd. Rūḥ al-Ma 'ānī. Beirut: Dār al-Fikr, 1987.

Al-Baghdādī, Abū Bakr Aḥmad bin 'Alī al-Khāṭib. Tārīkh alBaghdād. Beirut: Dār al-Kutub al-'Arabī, t.t.

Al-Dāwudī, Shams al-Dīn Muḥammad bin 'Alī Ibn Aḥmad. Tabaqāt al-Mufassirīn. Mesir : Maṭbaah Istiqlāl alKubrā,1972.

Al-Dhahabī, Husayn. Al-Tafsīr wa al-Mufassirūn. Kaherah: Maktabah Wahbah, t.t.

LTD, 2005. . Tafsir wal-Mufassirun. T.tp.: Avand Danesh

Al-Dhahabī, Shams al-Dīn Muḥammad bin Aḥmad bin 'Uthmān. Siyār A 'lam al-Nubalā' . Beirut: Muassasah al-Risalah,1988.

Al-Ḥamawī, Shihāb al-Dīn Abū 'Abd Allāh Yāqūt. Mujam Buldan. Beirut: Dār Șādir, 1987.

Al-Hamawī, Yāqūt. Mu'jam al-Udabā'. Beirut: Muassasah alMa'ārif, 1999.

Al-Hifnī, 'Abd al-Mun'īm. Mawsū 'ah al-Firāq wa al-Jama 'àt wa al-Madhāhib al-Islāmiyyah. Jāmi'ah al-Azhar : Dār alRassyad, 1993. 
Al-Khifnī, 'Abd al-Mun'īm. al-Mu 'jam al-Falsafí. Kaherah: Dār al-Syarqiyyah, 1990.

Al-Maghribī, 'Alī 'Abd al-Fattah. Imām Ahl al-Sunnah wa alJama 'ah: Abū Manșur al-Màturid̄̄ wa Ara'uhu Kalamiyah. Mesir: Maktabah Wahbah, 1983.

Al-Māturidī, Muḥammad Ibn Muḥammad. Tafsīr al-Qur'ān al'Ażìm al-Musammā Ta'wìlāt Ahl al-Sunnah. Beirut: Muassasah al-Risālah, 2004.

Al-Qurashī, al-Muḥy al-Dīn Abī Muḥammad 'Abd al-Qādir bin Muḥammad bin Muḥammad bin Nașr Allāh Ibn Sālim bin Abī al-Wafā'. Al-Jawāhir al-Mudiyyah fì Tabaqāt al-Hanafiyyah. Hijr: li al-țiba'ah wa al-Nashar wa al-Tawzi' wa al-I'lan, 1993.

Al-Samarqandī, Abu Layth. Tafsir al-Samarqandi al-Musamma Bahr al-'Ulum. Beirut : Dar al-Kutub al-'Ilmiyyah,1993.

Al-Suyūṭī, Jalāl al-Dīn 'Abd al-Raḥman. Al-Durr al-Manthūr. Beirut: Dār al-Fikr, 1993. . Al-Itqān fì 'Ulūm al-Qur'ān. Kaherah: Dār al-Turath, t.t.

Al-Ṭabarī, Abū Ja'far Muḥammad bin Jarīr. Jāmi' al-Bayān 'an Ta'wīl Āy al-Qur'ān. Kaherah: Dār al-Ma'arif, t.t.

Al-Wafā', Nașr Allāh Ibn Sālim bin Abī. al-Jawāhir al-Mudiyyah fi Tabaqāt al-Hanafiyyah. Hijr: Lil țiba'ah wa al-Nashr wa alawzi' wa al-I'lan, 1993.

Al-Zarkashī, Badr al-Dīn Muḥammad bin 'Abd Allāh. Al-Burhān fì 'Ulūm al-Qur'ān. Kaherah: Maktabah Dār al-Turath, t.t.

Al-Zubaydī, Muḥammad Murtaḍā al-Ḥusayn. Tāj al-'Arūs min Jawāhir al-Qāmūs. Beirut-Lubnan: Dār Maktabah al-Ḥayah, t.t.

Al-Zuhaylī, Muḥammad. Al-Imām al-Ṭabarī. Damsyik: Dār alQalam, 1990.

Al-Zurqān̄̄, Muḥammad 'Abd al-'Aẓīm. Manāhil al-'Irfān. Beirut: Dār al-Fikr, t.t.

Bakr, Ya'qūb dan al-Tawwab, Ramaḍān 'Abd. Tārīkh al-Adāb al'Araby. Cairo: Dār al-Ma'ārif, 2008.

Fayrūz Abādī, Mujīd al-Dīn Muḥammad bin Ya'qūb. Qāmūs alMuhit. Kaherah: Mu'assasah al-Halab̄i wa Shurakah li alNathr wa al-Tawji‘, t.t.

Haji Khalifah. Kashf al-Zunūn 'an Asami al-Kutub al-Funūn. Beirut-Lubnan: Dār Ihyā' al-Turath al-'Arabī, t.t. 
Ibn Manzūr, Abū al-Fạ̣l Jamāl al-Dīn Muhammad ibn Makram. Mukhtār al-Aghān̄̄ fì al-Akhbār wa al-Ṭahanī, (ed) Muhammad Abū al-Faụl Ibrāhīm. Kaherah: Maṭba'ah 'Īsā alBābī al-Halabī wa Syurakah, 1965.

Ibn Nadim. Al-Firisāt. Kaherah: Maktabah Tawfiqiyyah, t.t.

Muhammad Mustafizur Rahman. An Introduction to Al-Māturidī Ta'wīlāt Ahl al-Sunna. Bangladesh: Islamic Foundation Bangladesh, 1981.

Mūsā, Jalal Muḥammad. Nas 'at al-Ash 'ariyyah wa Tațāwwurihā. Lubnan: Dār al-Kitab al-Lubnānī, 1975.

Yahya Nuryadi. "Takwil dan Kesannya kepada Pengajian Tafsir: Analisis Terhadap Pemikiran Ibn Jarīr al-Ṭabarī dalam Mentafsir Ayat-ayat al-Qur'an". Disertasi, Jabatan al-Qur'an dan al-Hadith, Akademi Pengajian Islam, Universiti Malaya, 2005 . 
Aisyah, Zulkifli dan Zakirah, Terminologi Takwil Menurut al-Maturidi dan al-Tabari 